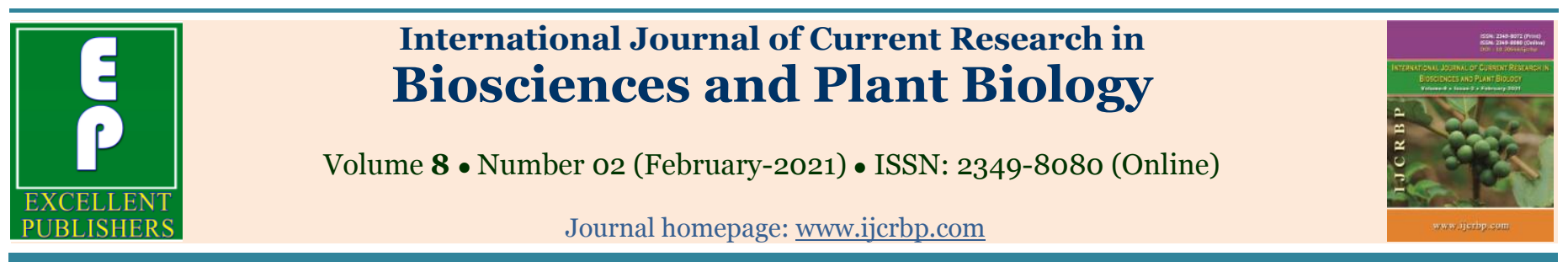

Original Research Article

doi: $\underline{\text { https://doi.org/10.20546/ijcrbp.2021.802.002 }}$

\title{
Ecophysiological responses of Phaseolus vulgaris L. to salinity and irrigation regimes in screen house
}

\section{Pascal Tabi Tabot ${ }^{1}{ }^{1}$, Mfombep Priscilla Mebong ${ }^{1}$, Achangoh Josaiah Abeche ${ }^{1}$, Nchufor Christopher Kedju ${ }^{1,2}$, Besingi Claudius Nyama ${ }^{1}$}

\author{
${ }^{1}$ Department of Agriculture, Higher Technical Teachers' Training College Kumba, \\ University of Buea, P.O. Box 249 Kumba, Cameroon \\ ${ }^{2}$ Ministry of Agriculture and Rural Development, Regional Delegation for the South West, \\ Republic of Cameroon
}

*Corresponding author; e-mail: ttabot@yahoo.com

\begin{tabular}{|c|c|}
\hline Article Info & Abstract \\
\hline $\begin{array}{l}\text { Keywords: } \\
\text { Deficit irrigation } \\
\text { Ecophysiological } \\
\quad \text { variables } \\
\text { Harvest index } \\
\text { Salinity stress } \\
\text { Water use efficiency }\end{array}$ & $\begin{array}{l}\text { Secondary salinization of arable lands, and declining irrigation water resources are major challenges } \\
\text { for crop production. We investigated synergistic effects of salinity and irrigation on Phaseolus vulgaris } \\
\text { L. in a } 4 \times 3 \text { factorial experiment with four salinity levels }(0,4,8 \text { and } 12 \mathrm{ppt} \text { ) coupled with } 3 \text { irrigation } \\
\text { regimes that reflected a deficit, normal and excess irrigation for the region. Growth and } \\
\text { ecophysiological variables were measured, and data submitted to Analyses of variance, Correlation } \\
\text { and Factor analyses in the Minitab Version } 17 \text { software. Salinity stress decreased height ( } 35.05 \text { to } \\
31.97 \mathrm{~cm}) \text { as salinity increased from } 0 \text { to } 8 \text { ppt. Number of leaves, number of branches, number of } \\
\text { flowers and fruits as well as fruit mass and harvest index all decreased as salinity stress increased. } \\
\text { Plants in the deficit irrigation regime had higher water use efficiency }(1.27 \mathrm{~g} / \mathrm{l}) \text { and transpiration use } \\
\text { efficiency ( } 29.51 \mathrm{~g} / \mathrm{l} \text { ) compared to those under higher irrigation regimes. Salinity and water stress } \\
\text { effects on yield and plant water relations would significantly impede production of this crop, with } \\
\text { significant yield losses of over } 400 \% \text { in higher salinities. Therefore measures to alleviate soil salinity } \\
\text { are necessary for enhanced } P \text {. vulgaris production in such saline contaminated areas. }\end{array}$ \\
\hline
\end{tabular}

- Received: 8 December 2020 • Revised: 19 January 2021 • Accepted: 23 January 2021 • Published Online: 6 February 2021

\section{Introduction}

Global agriculture faces two major challenges - one of sustainably producing sufficient food for the worlds' growing population under increasingly limited natural resources, and the second, of producing enough nutritive foods to reduce hidden hunger (Muthayya et al., 2013). Of the resources that most limits food production, availability of suitable irrigation water probably ranks as the top limiting resource. Due to climate change, precipitation patterns are also changing, rendering once reliably rainfed crop production systems unsustainable either due to rainfall shortage that results in drought stress, or excess rainfall which results in waterlogging stress (Kabir and Golder, 2017). Drought stress occurs in plants when levels of soil moisture drop below critical thresholds. Soil water potential reduces during drought, and simultaneously the ability of plants 
to take up water also reduces (Schwinning et al., 2005). Nutrient uptake reduces either as a result of diminished transpirational flow, inadequate water for nutrient dissociation in solution and failure of unloading mechanisms in the plants concerned (Farooq et al., 2009). In plants, the general response is increased stomatal resistance to reduce water loss (Takahashi et al., 2020), which results also in decreased photosynthesis rates as the levels of $\mathrm{CO}_{2}$ intake reduce.

Increased rainfall events are also predicted to increase in frequency, and when they do occur, waterlogging of soils occurs, as the macropore spaces become inundated. Soils become hypoxic or anoxic, as the $\mathrm{pH}$, redox potential and oxygen levels are altered (Ashraf, 2012). Plant root respiration is inhibited in these conditions for susceptible plants, and glycolysis becomes the main route of energy generation which is highly costly to plants and less efficient (Ashraf, 2012). Perhaps due to low oxygen diffusion rates, anoxia quickly builds up, root functioning is highly impaired and nutrient uptake drops significantly (Elzenga and Van Veen, 2010). In susceptible plants, the result ultimately is reduced growth, while tolerant plants would display a suit of responses that enable them to survive the stress in the short or long term.

A further implication of declining water resources is secondary salinization of arable land that typically results from anthropogenic activities like irrigation with substandard water, and some forms of abusive soil fertilization with inorganics (Shrivastava and Kumar, 2015). Salinity reduces water availability to plants by lowering the water potential such that the plant is disadvantaged; reduced water uptake directly limits nutrient uptake but more importantly, nutrients become fixed as they associate with the different dissociated components of salts in the saline soil solution and these fixed nutrients cannot be taken up by the plants (Majeed and Siyyar, 2020). The resulting water and nutrient imbalance as well as specific ion toxicity effects reduce crop growth and development. Moreover, like other stressors, salinity stress elicits an uptick in the concentration of reactive oxygen species (ROS) within the plant which breakdown/destabilize plant cell membranes, proteins and DNA, and the plant response to these necessitates among others, a re-allocation of resources from the already highly limited photosynthesis, from growth and yield, to stress response, for example synthesis of proline and other compatible osmolytes required for osmotic balance and stabilization of membranes and proteins (Munns and Tester, 2008).

Irrespective of the stressor, the effects on crop growth, development and yield would be catastrophic for susceptible plants, further aggravating the food insecurity and hidden hunger problem. In attempting to find plants that would thrive in these extreme conditions, emphasis is often paid to grain and cash crops that have a high calorie value but may possess very little nutritional value. Vegetables are high valued plants with the nutritive value to ameliorate the effects of hidden hunger. Among the most important fruit vegetables in cuisines worldwide is Phaseolus vulgaris L. This species is a formidable source of fibre, proteins and vitamins in most diets. Several authors have looked into its responses to unique stressors, for example how it responds to salinity stress (Taïbi et al., 2016; Can Chulim et al., 2017; Nadeem et al., 2019), or its responses to drought (Sadeghipour and Aghaei, 2012; Erhenhi, 2020) and waterlogging stress (Ntukamazina et al., 2017; Erhenhi, 2020) but few records exist on synergistic effects of these stressors on the species, as would be the case in natural cropping systems. The aim of this research was to investigate the ecophysiological responses of $P$. vulgaris to synergistic effects of salinity and irrigation regimes in screen house that mimic the predicted conditions. The results could prove significant in guiding producers on water management in a water deficit or surplus scenario compounded by salinity stress.

\section{Materials and methods}

\section{Environmental conditions in the screen house}

The screen house was constructed at the Divisional Delegation for Agriculture and Rural Development for Meme, Kumba, Cameroon located at the geographical coordinates $4^{\circ} 38^{\prime} \mathrm{N} 9^{\circ} 27^{\prime} \mathrm{E}$ and $4.63^{\circ} \mathrm{N} 9.45^{\circ} \mathrm{E}$ and an elevation of 240 meters $(790 \mathrm{ft})$ above sea level. The roof was covered with transparent polythene typically used for greenhouses, estimated to have over $90 \%$ light transmission potential.

\section{Study species}

Phaseolus vulgaris L., specifically the French F1 dwarf variety called HARICOT CORA, with $99 \%$ purity and $85 \%$ germination rate imported and distributed by SEMAGRI SARL, Cameroon, was used for this study. 
It is commonly known as green beans. This variety has the potential of a very short production cycle from planting to harvest, and its production is less strenuous as it does not require staking.

\section{Experimental design}

The experimental design was a 3 by 4 factorial design with two factors, namely, salinity and irrigation. There were four salinity levels $\left(S_{1}=0 \mathrm{ppt}, \mathrm{S}_{2}=4 \mathrm{ppt}\right.$, $\mathrm{S}_{3}=8 \mathrm{ppt}$ and $\mathrm{S}_{4}=12 \mathrm{ppt}$ ) obtained by dilution of seawater with freshwater. Also, there were three irrigation regimes namely $\mathrm{I}_{1}$ corresponding to 1100 $\mathrm{mm}$, which is half the mean annual rainfall for Kumba. This treatment represented a deficit irrigation scenario, and each pot received $1.5 \mathrm{~L}$ of irrigation water per week; $\mathrm{I}_{2}$ corresponded to $2200 \mathrm{~mm}$ per year, which is the mean annual rainfall for the region, and for this treatment plants received $3 \mathrm{~L}$ of irrigation water per week; and $\mathrm{I}_{3}$ corresponding to $3300 \mathrm{~mm}$ which is one and a half times the normal irrigation for the region represented a situation of excess rainfall for which each pot was irrigated with $4.5 \mathrm{~L}$ of irrigation water. When combined with the three salinity levels, this gave a total of 12 treatments. There were 3 replicates for each treatment, for a total of 36 experimental units. There was randomization within the screen house to ensure a more uniform micro environment across treatments.

\section{Pre-planting soil analysis}

Top soil was collected from the plough layer (top 30 $\mathrm{cm}$ ) in a fallow area within the research site. The soil was homogenized and used to fill 36 plastic pots of volume $10 \mathrm{~L}$ each with a surface area of $530.9 \mathrm{~cm}^{2}$. Each pot was perforated with 12 holes on the sides and ten holes below, for water infiltration and to avoid waterlogging. A representative sample of the soil was sent to the Plant and Soil laboratory of the University of Dschang analysis. The characteristics of this soil are presented on Table 1 . The soil was sandy clay, slightly acidic, rich in organic matter, with suitable levels of exchangeable cations (Table 1). The nitrogen concentrations were high enough for green beans cultivation, since the crop is a legume with ability to fix nitrogen.

\section{Agronomic operations}

Four seeds were planted directly in the pots. Germination occurred within 3 days, with emergence from the $5^{\text {th }}$ day. The plants were irrigated three times a week at regular intervals with freshwater for two weeks until they were fully established. Then the different treatments were applied. Weeding was done regularly to prevent competition and control pests. Ridomil Gold fungicide and Onex Super insecticide were sprayed twice a week to ensure the plants were free from disease.

Table 1. Characteristics of soils used for the experiment.

\begin{tabular}{llll}
\hline Soil Property & Value & Soil Property & Value \\
\hline Texture & Sandy clay & Exchangeable cations (me/100g) & \\
pH $(\mathrm{KCl})$ & 4.7 & Magnesium & 0.88 \\
Organic Matter & & Potassium & 1.67 \\
Organic carbon $(\%)$ & 4.24 & Sodium & 0.34 \\
Organic matter $(\%)$ & 7.31 & Total & 4.73 \\
Total nitrogen $(\mathrm{g} / \mathrm{kg})$ & 0.77 & Exchangeable acidity (me/100g) & \\
C/N ratio & 55.08 & H+ Al (EA) & \\
& & Cation exchangeable capacity (CEC) & \\
& Effective CEC & 9.12 \\
\hline
\end{tabular}

$\mathrm{KCl}=$ potassium chloride, $\mathrm{me}=$ milliequivalent, $\mathrm{CEC}=$ cation exchange capacity .

\section{Application of treatments}

The treatments commenced two weeks after transplanting. For each salinity level, the three replicates of each treatment were irrigated with the respective volumes of irrigation water as described in Section 2.2. Irrigation water for each week was applied in three split applications. For one replicate of the treatments, the schedule of treatments is shown in Fig. 1.

\section{Data collection}

Collection of data commenced two weeks after transplanting for baseline measurements of height, 
number of branches, number of leaves, leaf area, rate of transpiration, number of flowers, number of fruits, fruit size, fruit weight, chlorophyll concentration and plant biomass.

\section{Growth parameters}

Plant height, number of leaves, leaf area and number of branches were measured weekly. Plant height was measured from the base to the crown of the plant using a meter tape graduated in millimetres. The total number of leaves was obtained by counting. Leaf area was measured using the method of (Pandey and Singh, 2011). The average leaf area of the traced leaves was then multiplied by the total number of leaves on the plant to have the total leaf area available for photosynthesis. The total number of branches was also determined by counting.

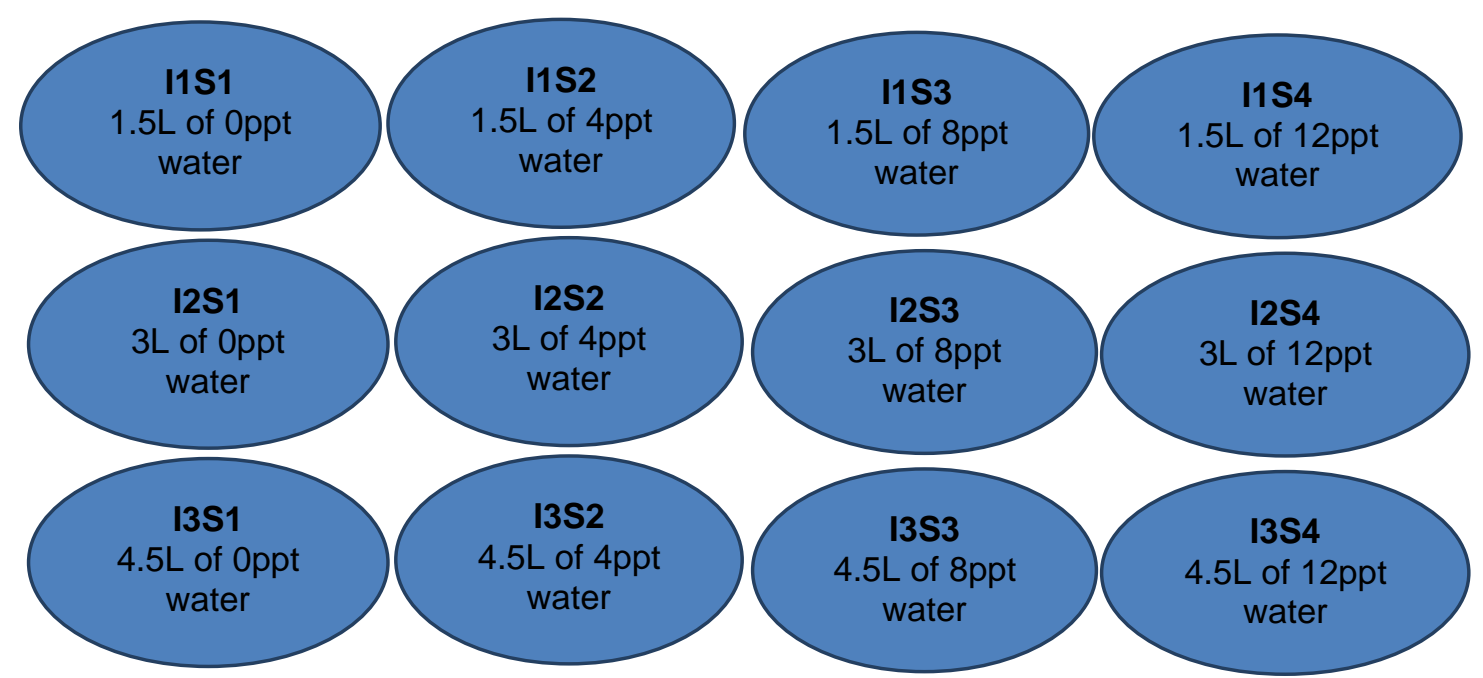

Fig. 1: Treatments applied according to a $3 \times 4$ factorial design of 3 irrigation levels (I1 to I3) and 4 salinity levels S1 to S4.

\section{Chlorophyll concentration}

Uniform leaf discs measuring $1 \mathrm{~cm}$ in diameter, were collected from intact leaves still attached, and placed in vials with $10 \mathrm{ml} \mathrm{95 \%} \mathrm{ethanol} \mathrm{in} \mathrm{the} \mathrm{cold} \mathrm{room} \mathrm{for} 24$ hours to extract. The absorbances were then read in a Cyanscan Spectrophotometer at 664.1 and $648.8 \mathrm{~nm}$. Chlorophyll concentration was then calculated according to Lichtenthaler et al. (1984) as follows:

$$
C_{\mathrm{a}+\mathrm{b}}=5.24 \mathrm{~A}_{664.2}+22.24 \mathrm{~A}_{648.6} \ldots \ldots \ldots .1
$$

Where,

$\mathrm{A}=$ absorbance, $C_{\mathrm{a}}=$ chlorophyll $\mathrm{a}, C_{\mathrm{b}}=$ chlorophyll $\mathrm{b}$, $C_{\mathrm{a}+\mathrm{b}}=$ total chlorophyll

\section{Biomass partitioning, fruit yield and harvest index}

At the start of measurements, an initial sample of 20 plants were harvested and weighed, then separated into roots and shoots, oven-dried separately at $60^{\circ} \mathrm{C}$ to constant mass and re-weighed to obtain the dry mass, which was then averaged to get the initial dry mass per plant for each fraction. At the end of the experiment, this was repeated for two plants from each treatment to obtain the final dry mass for each fraction. A sample of fruits were equally weighed fresh, then oven-dried to constant mass at $60^{\circ} \mathrm{C}$, then re-weighed to get the dry mass. This was used to establish a regression equation from which dry mass of all subsequent harvest was determined. The final biomass was a combination of root, shoot and fruit dry masses:

Biomass of plant $(g)=$ root $D M(g)+$ shoot $D M(g)+$ fruit $D M(g) \ldots \ldots \ldots 2$

Where,

$\mathrm{DM}=$ dry mass

Fruits produced in each replicate were counted cumulatively from the beginning to the end of the experiment, and averaged for the number of plants to obtain the number of fruits per plant. The fruits per plant were also weighed fresh to obtain the fruit mass. The harvest index was determined as the ratio of the economic to the biological yield:

$$
H I=\frac{\text { Economic yield }(g)}{\text { Biological yield }(g)} \text { that is, } \frac{\text { Fruit fresh mass }(g)}{\text { Plant Biomass }(g)} \ldots \ldots . . .3
$$




\section{Ecophysiological parameters}

\section{Water use efficiency (WUE)}

The volume of water used for irrigation was recorded for the duration of the experiment. At the end of the experiment, the biomass was measured as previously explained. The water use efficiency represents the ratio of biomass accumulated per unit volume of irrigation water, according to [20]:

$$
\text { WUE }=\left(\frac{g}{l}\right)=\frac{\text { Total plant Biomass }}{\text { Total volume of irrigation water } \ldots . . . . .4}
$$

\section{Transpiration rate}

To determine the transpiration rate, the mass difference method was used. Each pot was placed in an intact transparent polythene bag and irrigated with its corresponding irrigation regime. The pots were then completely sealed by tying around the stems of the tomato plants, so that the only possible avenue of water loss would be through transpiration. The pots were weighed using a digital balance to get the initial mass (w1) at $8 \mathrm{am}$. At $1 \mathrm{pm}$ the pots were re-weighed to obtain the final mass (w2). The rate of transpiration was determined as follows:

$$
T R\left(\frac{g}{h r}\right)=\frac{w 1-w 2}{t} \ldots \ldots \ldots 5
$$

Where,

$\mathrm{TR}=$ Transpiration rate, $\mathrm{w} 1=$ initial mass of irrigated pot and plant, w2 = final mass of irrigated pot and plant.

\section{Transpiration Use Efficiency (TUE)}

Transpiration use efficiency measures the efficiency of water conservation relative to biological production and was determined by:

$$
\operatorname{TUE}\left(\frac{\mathrm{g}}{\mathrm{L}}\right)=\frac{\text { total plants biomass }}{\text { total amount of water lost by transpiration }} \ldots \ldots \ldots 6
$$

\section{Relative growth rate (RGR)}

The relative growth rate was calculated according to Tabot and Adams (2012):

$$
R G R=\frac{\ln w 2-\ln w 1}{t 2-t 1} \ldots \ldots . . .7
$$

Where,

$\mathrm{RGR}=$ relative growth rate, $\ln =$ natural logarithm and $\mathrm{t} 2$ - $\mathrm{t} 1=$ duration of measurement

\section{Succulence}

Succulence was measured as the ratio of the moisture content to the dry mass:

$$
\text { Succulence }=\frac{F m(g)-\operatorname{Dm}(g)}{\operatorname{Dm}(g)} \ldots \ldots . . .8
$$

Where,

$\mathrm{Fm}=$ fresh mass of shoot, Dm = dry mass of shoot

\section{Shoot Mass Fraction (SMF)}

The shoot mass fraction was calculated as a ratio of the mass of the shoot to the total plant biomass.

$$
S M F=\frac{\text { Shoot mass }(g)}{\text { Total plant biomass }(g)} \ldots \ldots . . .9
$$

\section{Root:Shoot ratio}

The Root shoot ratio was determined as the fraction of the root dry mass to shoot dry mass:

$$
\text { Root: shoot ratio }=\frac{\text { root dry mass }(g)}{\text { Shoot dry mass }(g)} \ldots \ldots 10
$$

\section{Data analysis}

Data were tested for normality and homogeneous variance. They were then subjected to GLM ANOVA with interactions, in tandem with Tukey HSD test at $\alpha=$ 0.05 . Growth Data that were not normally distributed were Cox-Box transformed using the natural log function during analysis. For parameters that were measured over time, Spearman rank correlation was done to determine data covariance and the relationship between parameters, while for those measured at the end of the experiment which were normally distributed, Pearson correlation was done.

Factor analysis based on data correlation was done to identify the spatial relationships and contribution of the different factors to the observed variability in the data. All analyses were done in the Minitab Version 17 statistical package (Minitab Inc., PA, USA) and where necessary, significance was determined at the $95 \%$ level $(\alpha=0.05)$. 


\section{Results}

\section{Visual observations}

Fig. 2 shows some visual observations during the experiment. The salinity effect on growth is obviously a decrease as salinity increases (A). However, plants were able to sustain and grow to maturity in all treatments, such that yield could be measured and reported (B). Also, there were clear signs of specific ion toxicity on leaves of the plants, which is typical of plants susceptible to salinity stress (C and D).
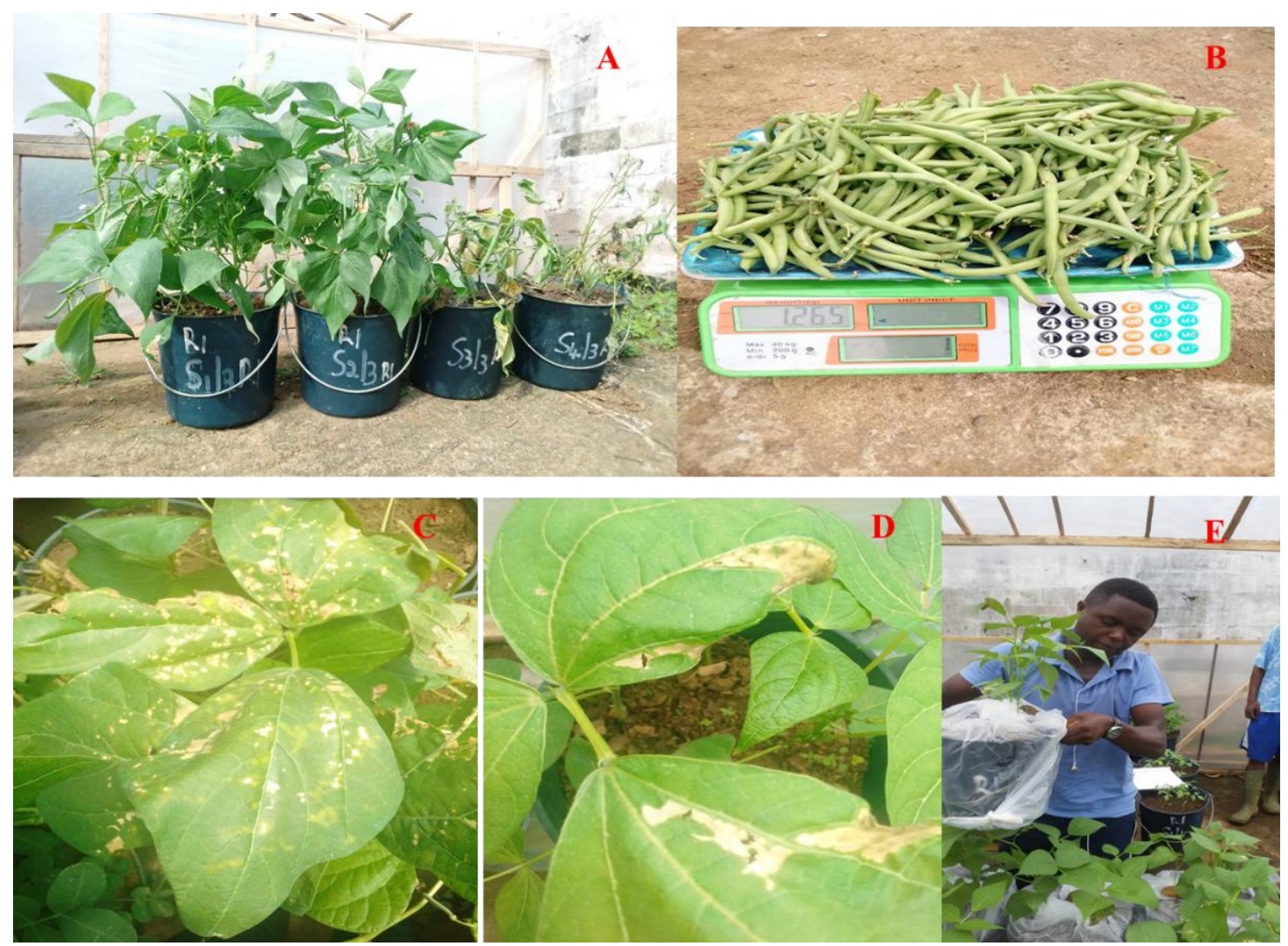

Fig. 2: Visual observations of responses of Phaseolus vulgaris to salinity and irrigation regimes in screen house. $\mathrm{A}=$ decrease in growth as salinity increases from 0 to $12 \mathrm{ppt} ; \mathrm{B}=$ measurement of yield; $\mathrm{C}$ and $\mathrm{D}=$ signs of specific ion toxicity on beans leaves; $\mathrm{E}=$ measurement of transpiration rate.

\section{Growth responses of green beans to salinity and irrigation in screen house}

Salinity stress had a significant effect on height and number of branches of green beans $(p<0.05)$ while irrigation significantly influenced leaf area $(\mathrm{p}=0.039)$. All variables (height, number of branches, number of leaves and leaf area) varied significantly over time $(\mathrm{p}<0.001)$. There were no significant interaction effects on any of the growth parameters. Table 2 shows plants irrigated with freshwater (0ppt) were significantly taller compared to those at $8 \mathrm{ppt}$, and number of branches decreased significantly as salinity increased $(7.33$ at 0 ppt to 6.42 at $12 \mathrm{ppt}$ ). Number of leaves decreased as salinity increased, but leaf area was statistically similar (Table 2).

\section{Chlorophyll concentrations}

Chlorophyll concentrations varied significantly over time $(\mathrm{p}=0.000)$ and with the irrigation treatment $(\mathrm{p}<0.05)$ but salinity stress did not significantly affect chlorophyll concentrations $(p>0.05)$. There was no significant interaction effect on chlorophyll concentrations. Chlorophyll concentrations at the deficit irrigation level were significantly higher compared to those in plants under excess irrigation (Table 3).

There were no correlations between salinity and most of the measured growth variables and chlorophyll concentrations ( $p>0.05)$, except for a weak negative correlation between salinity and number of leaves $(\mathrm{p}=$ 
$0.022, \rho=-1.91)$ but strong covariance between the measured growth and chlorophyll variables. On the other hand the growth variables were highly time- dependent. Factor analysis of the correlation matrix shows that salinity and irrigation account for $62.3 \%$ of the total variability in the data (Fig. 3).

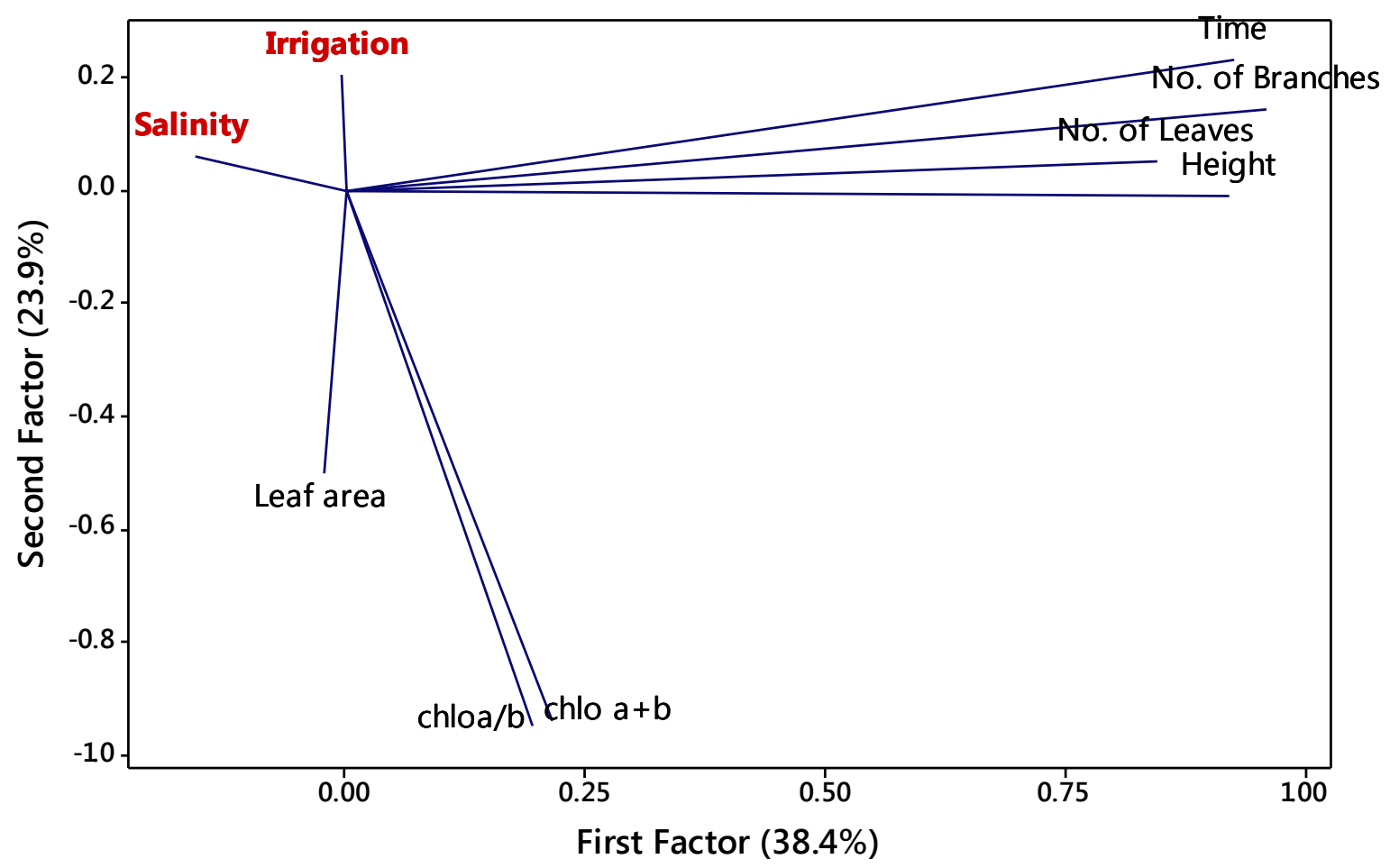

Fig. 3: Factor analysis of the correlation matrix showing association of growth and chlorophyll parameters of Phaseolus vulgaris with treatments.

\section{Yield parameters}

Salinity significantly influenced the number of fruits $(\mathrm{p}$ $=0,000)$, fruit mass $(\mathrm{p}=0.000)$, reproductive success $(\mathrm{p}$ $=0.042)$ and harvest index (0.003). There were no significant irrigation effects on these parameters. Table 4 shows the effects of salinity and irrigation on yield parameters. Number of flowers, number of fruits, fruit mass and Harvest index were significantly higher for plants irrigated with freshwater, and decreased as salinity increased, but biomass was statistically constant across salinity treatments.

There were strong negative correlations between salinity and number of flowers $(\mathrm{p}=0.004, \mathrm{r}=-0.464)$, number of fruits $(\mathrm{p}=0.000, \mathrm{r}=-0.816)$, fruit mass $(\mathrm{p}=0.000, \mathrm{r}=-0.641)$, reproductive success $(\mathrm{p}=0.012, \mathrm{r}$ $=-0.415)$, biomass $(\mathrm{p}=0.023, \mathrm{r}=-0.377)$ and Harvest Index $(p=0.002, r=-0.506)$. Factor analysis of the correlation matrix (Fig. 4) shows that salinity and irrigation accounted for $64.9 \%$ of the observed variability in the yield data, with the expression of yield parameters highly salinity-dependent $(64.1 \%)$ compared to the minimal irrigation effect (18.8\%).

\section{Ecophysiological responses}

Analysis of variance results showed that salinity significantly influenced transpiration use efficiency ( $p$ $=0.001)$, shoot mass fraction $(\mathrm{p}=0.011)$ and root:shoot ratio $(\mathrm{p}=0.017)$, while irrigation significantly influenced plant water use efficiency $(\mathrm{p}=$ $0.000)$, transpiration rate $(\mathrm{p}=0.0010$ and transpiration use efficiency $(\mathrm{p}=0.000)$. There was no significant interaction effect. Table 5 shows the ecophysiological responses of $P$. vulgaris to salinity and irrigation regimes in screen house. As salinity increased from 0 to $12 \mathrm{ppt}$, transpiration use efficiency drops from $25.67 \mathrm{~g} / 1$ to $18.93 \mathrm{~g} / \mathrm{l}$ and shoot mass fraction from 0.73 to 0.65 . For corresponding salinity levels, root:shoot ratio increased from 0.38 to 0.56 . On the other hand, water use efficiency and transpiration use efficiency both decreased as irrigation water volume increased (Table 5). 
Table 2. Growth responses of green beans to different levels of salinity and irrigation in screen house.

\begin{tabular}{lllll}
\hline Salinity (ppt) & Height $(\mathbf{c m})$ & No. of branches & No. of leaves & LA $\left(\mathbf{c m}^{2}\right)$ \\
\hline 0 & $35.05 \mathrm{a}$ & $7.33 \mathrm{a}$ & $24.58 \mathrm{a}$ & $52.92 \mathrm{a}$ \\
4 & $34.95 \mathrm{ab}$ & $7.78 \mathrm{ab}$ & $20.97 \mathrm{ab}$ & $53.43 \mathrm{a}$ \\
8 & $31.97 \mathrm{~b}$ & $7.00 \mathrm{~b}$ & $17.49 \mathrm{~b}$ & $52.04 \mathrm{a}$ \\
12 & $32.49 \mathrm{ab}$ & $6.42 \mathrm{~b}$ & $16.58 \mathrm{~b}$ & $48.24 \mathrm{a}$ \\
Irrigation (l/pot/week) & & & \\
1.5 & $33.45 \mathrm{a}$ & $7.08 \mathrm{a}$ & $19.31 \mathrm{a}$ & $55.03 \mathrm{a}$ \\
3 & $33.43 \mathrm{a}$ & $7.15 \mathrm{a}$ & $20.65 \mathrm{a}$ & $48.89 \mathrm{a}$ \\
4.5 & $34.01 \mathrm{a}$ & $7.17 \mathrm{a}$ & $19.81 \mathrm{a}$ & $51.03 \mathrm{a}$ \\
\hline
\end{tabular}

Values represent means. Means separated through GLM ANOVA with Tukey HSD test at $\alpha=0.05$. Means with the same letter within the column for each main effect are not significantly different. LA = leaf area

Table 3. Chlorophyll responses of green beans to different levels of salinity and irrigation in screen house.

\begin{tabular}{|c|c|c|c|c|}
\hline Salinity (ppt) & Chl a $\left(\mu g^{-1}\right)$ & Chl b $\left(\mu g^{-1}\right)$ & Chl $\mathbf{a}+\mathbf{b}\left(\left.\mu g\right|^{-1}\right)$ & Chl a/b $\left(\mu g l^{-1}\right)$ \\
\hline 0 & $2.22 \mathrm{a}$ & $6.45 \mathrm{a}$ & $8.67 \mathrm{a}$ & $0.34 \mathrm{a}$ \\
\hline 4 & $2.21 \mathrm{a}$ & $6.41 \mathrm{a}$ & $8.61 \mathrm{a}$ & $0.34 \mathrm{a}$ \\
\hline 8 & $2.25 \mathrm{a}$ & $6.50 \mathrm{a}$ & $8.74 \mathrm{a}$ & $0.35 \mathrm{a}$ \\
\hline 12 & $2.20 \mathrm{a}$ & $6.38 \mathrm{a}$ & $8.58 \mathrm{a}$ & $0.34 \mathrm{a}$ \\
\hline \multicolumn{5}{|c|}{ Irrigation (1/pot/week) } \\
\hline 1.5 & $2.25 \mathrm{a}$ & $6.50 \mathrm{a}$ & $8.75 \mathrm{a}$ & $0.35 \mathrm{a}$ \\
\hline 3 & $2.21 \mathrm{ab}$ & $6.42 \mathrm{ab}$ & $8.64 a b$ & $0.34 \mathrm{ab}$ \\
\hline 4.5 & $2.19 \mathrm{~b}$ & $6.38 \mathrm{~b}$ & $8.57 \mathrm{~b}$ & $0.34 \mathrm{~b}$ \\
\hline
\end{tabular}

Values represent means. Means separated through GLM ANOVA with Tukey HSD test at $\alpha=0.05$. Means with the same letter within the column for each main effect are not significantly different. $\mathrm{Chl}=$ chlorophyll.

Table 4. Yield responses of Phaseolus vulgaris to salinity and irrigation in screen house.

\begin{tabular}{lllllll}
\hline Salinity & No. of flowers & No. of fruits & Fruit mass $(\mathbf{g})$ & RS & Biomass $(\mathbf{g})$ & HI \\
\hline 0 & $36.89 \mathrm{a}$ & $25 \mathrm{a}$ & $57.1 \mathrm{a}$ & $70.71 \mathrm{a}$ & $10.68 \mathrm{a}$ & $6.15 \mathrm{a}$ \\
4 & $31.67 \mathrm{ab}$ & $15.89 \mathrm{~b}$ & $45.22 \mathrm{ab}$ & $78.9 \mathrm{a}$ & $7.20 \mathrm{a}$ & $6.38 \mathrm{a}$ \\
8 & $28.33 \mathrm{ab}$ & $7.44 \mathrm{c}$ & $20.67 \mathrm{bc}$ & $26.39 \mathrm{a}$ & $6.64 \mathrm{a}$ & $3.157 \mathrm{ab}$ \\
12 & $23.33 \mathrm{~b}$ & $3.778 \mathrm{c}$ & $13.89 \mathrm{c}$ & $18.92 \mathrm{a}$ & $6.81 \mathrm{a}$ & $2.156 \mathrm{~b}$ \\
Irrigation & & & & & & \\
1.5 & $30.92 \mathrm{a}$ & $14.75 \mathrm{a}$ & $35.17 \mathrm{a}$ & $44.96 \mathrm{a}$ & $7.61 \mathrm{a}$ & $4.75 \mathrm{a}$ \\
3 & $32.58 \mathrm{a}$ & $10.83 \mathrm{a}$ & $35.92 \mathrm{a}$ & $34.77 \mathrm{a}$ & $8.16 \mathrm{a}$ & $4.37 \mathrm{a}$ \\
4.5 & $26.67 \mathrm{a}$ & $13.5 \mathrm{a}$ & $31.58 \mathrm{a}$ & $66.4 \mathrm{a}$ & $7.72 \mathrm{a}$ & $4.27 \mathrm{a}$ \\
\hline
\end{tabular}

Values represent means. Means separated through GLM ANOVA with Tukey HSD test at $\alpha=0.05$. Means with the same letter within the column for each main effect are not significantly different. $\mathrm{HI}=$ harvest index

Table 5. Ecophysiological responses of Phaseolus vulgaris to salinity and irrigation regimes in screen house.

\begin{tabular}{|c|c|c|c|c|c|c|c|}
\hline Salinity (ppt) & WUE $\left(\mathrm{gl}^{-1}\right)$ & TR (1/hr) & TUE $\left(\mathrm{gl}^{-1}\right)$ & RGR (g/g/week) & Succulence & SMF & R:S \\
\hline 0 & $0.984 \mathrm{a}$ & $0.1125 \mathrm{a}$ & $25.67 \mathrm{a}$ & $0.17 \mathrm{a}$ & $2.53 \mathrm{a}$ & $0.73 \mathrm{ab}$ & $0.38 \mathrm{ab}$ \\
\hline 4 & $0.784 a$ & $0.1383 \mathrm{a}$ & $17.19 \mathrm{~b}$ & $0.13 \mathrm{a}$ & $2.78 \mathrm{a}$ & $0.75 \mathrm{a}$ & $0.33 b$ \\
\hline 8 & $0.664 a$ & $0.1408 \mathrm{a}$ & $15.85 b$ & $0.12 \mathrm{a}$ & $2.03 \mathrm{a}$ & $0.65 b$ & $0.58 \mathrm{a}$ \\
\hline 12 & $0.738 \mathrm{a}$ & $0.1025 a$ & $18.93 b$ & $0.11 \mathrm{a}$ & $2.08 \mathrm{a}$ & $0.65 b$ & $0.56 \mathrm{ab}$ \\
\hline \multicolumn{8}{|c|}{ Irrigation (1/pot/week) } \\
\hline 1.5 & $1.268 \mathrm{a}$ & $6.729 \mathrm{a}$ & $29.51 \mathrm{a}$ & $0.1326 \mathrm{a}$ & $2.25 \mathrm{a}$ & $0.67 \mathrm{a}$ & $0.53 \mathrm{a}$ \\
\hline 3 & $0.68 b$ & $0.1383 b$ & $15.62 b$ & $0.1337 \mathrm{a}$ & $2.52 \mathrm{a}$ & $0.73 \mathrm{a}$ & $0.38 \mathrm{a}$ \\
\hline 4.5 & $0.4287 \mathrm{~b}$ & $0.165 b$ & $13.1 \mathrm{~b}$ & $0.1277 \mathrm{a}$ & $2.29 \mathrm{a}$ & $0.69 \mathrm{a}$ & $0.48 \mathrm{a}$ \\
\hline
\end{tabular}

Values represent means. Means separated through GLM ANOVA with Tukey HSD test at $\alpha=0.05$. Means with the same letter within the column for each main effect are not significantly different. WUE = water use efficiency; TR = Transpiration rate;

$\mathrm{TUE}=$ Transpiration use efficiency; RGR = relative growth rate; SMF = shoot mass fraction; R:S = root:shoot ratio 


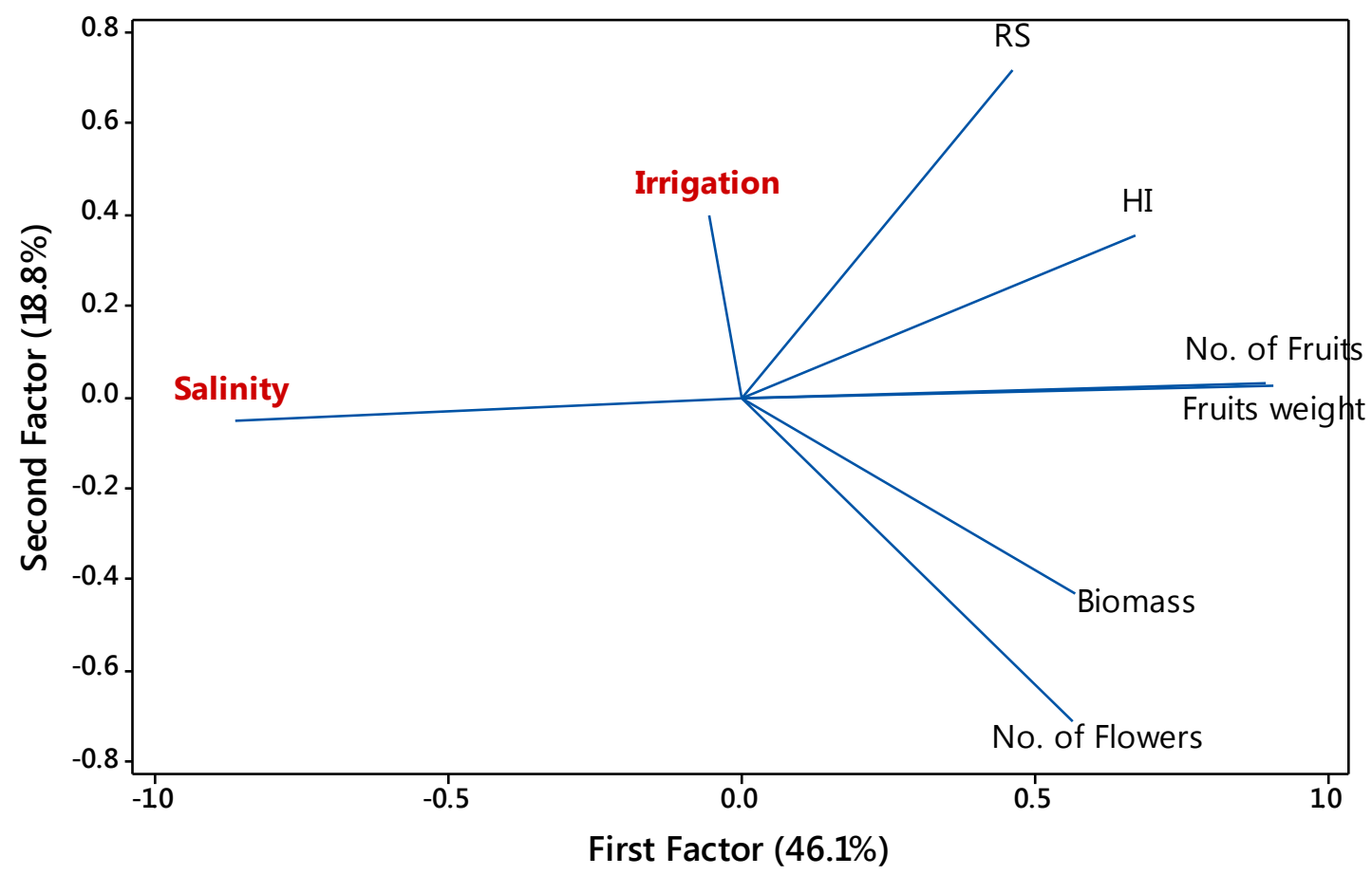

Fig. 4: Factor analysis of the correlation matrix of the relationship between salinity and irrigation stressors on the yield parameters of Phaseolus vulgaris in screen house.

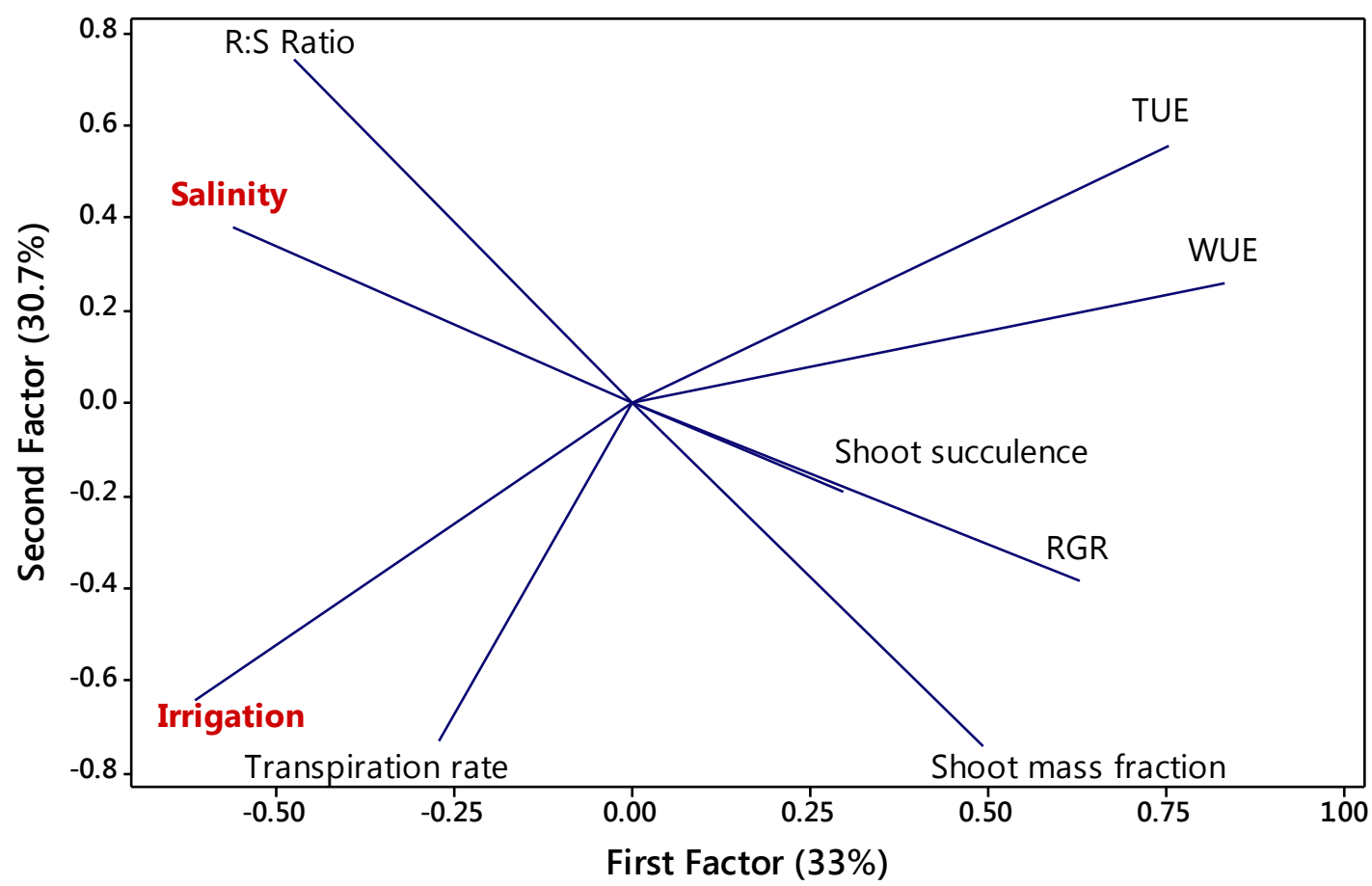

Fig. 5: Factor analysis of the correlation matrix of the relationship between salinity and irrigation stressors on the ecophysiological parameters of Phaseolus vulgaris in screen house

There were strong negative correlations between salinity and relative growth rate $(\mathrm{p}=0.013, \mathrm{r}=-0.411)$, shoot succulence $(\mathrm{p}=0.038, \mathrm{r}=-0.347)$, shoot mass fraction $(\mathrm{p}=0.010, \mathrm{r}=-0.424)$ and a positive correlation with root:shoot ratio $(\mathrm{p}=0.017, \mathrm{r}=0.396)$. The correlations between irrigation on the one hand and water use efficiency and transpiration use efficiency on the other were strongly negative $(\mathrm{p}=0.000, \mathrm{r}=0.076$ 
for both) while there was a positive correlation between irrigation and transpiration rate $(\mathrm{p}=0.000, \mathrm{r}=0.565)$. Factor analysis of the correlation matrix shows that the treatments contribute to explain $63.7 \%$ of the observed variation in ecophysiological variables. There is a strong negative association salinity, shoot succulence and shoot mass fraction, similar to the negative association between irrigation, transpiration use efficiency and water use efficiency (Fig. 5).

\section{Discussion}

Salinity stress decreased all growth variables of $P$. vulgaris measured. This is the expected trend for plants susceptible to salinity stress. Decrease in growth with increase in salinity is often a result of cascading effects of disruption in water and nutrient balance, oxidative stress and ionic toxicity (Volkov and Beilby, 2017). Without adequate water, cells lose turgidity, cell elongation reduces and the biochemical processes that should power growth and development are down regulated. In detail, the processes leading to growth reduction due to salt stress include interruption of membranes, nutrient imbalance, impaired ability to detoxify reactive oxygen species (ROS) (because of nutrient limitation for production of compatible osmolytes), differences in the antioxidant enzymes and decreased photosynthetic activity due mainly to increased stomatal resistance (Gupta and Huang, 2014). Furthermore, accumulation of $\mathrm{Na}^{+}$and $\mathrm{Cl}^{-}$ions in tissues of plants exposed to soils with high $\mathrm{NaCl}$ concentrations results in ion imbalance, inhibits uptake of $\mathrm{K}^{+}$ions which is an essential element for growth and development and hence results in lower productivity (Gupta and Huang, 2014). We found clear evidence of specific ion toxicity on the leaves of $P$. vulgaris in this experiment, which indicate its susceptibility to salt stress.

Another common response of plants to salinity stress is decrease in chlorophyll concentrations (Azizov, Khanisheva and Ibrahimova, 2013). In the current study however, there were no significant differences in chlorophyll concentration with salinity increase; however, chlorophyll concentrations decreased as irrigation water increased. Increasing irrigation to $150 \%$ the current mean annual precipitation as was the case in this study typically leaves the soils over saturated, and the consequence is waterlogging stress. Waterlogging causes membrane lipid peroxidation and damage to organelles like chloroplasts, ultimately resulting in declined chlorophyll concentrations (Irfan et al., 2010; Ren et al., 2016). Decreased chlorophyll formation and damaged photosynthetic apparatus is directly linked to reduced yields in plants under waterlogging, in addition to poor water and nutrient uptake, anoxia and associated anaerobic fermentation that generates much reduced ATP for biochemical processes (Wang et al., 2017; Tian et al., 2019). Factor analysis of variables in the current study shows a strong negative association between irrigation and chlorophyll concentration.

In terms of yield however, we found that salinity stress was a stronger determinant of yield, when combined with irrigation regimes. In the present study, there was a significant decrease in yield parameters like number of flowers, number of fruits, fruit mass, reproductive success, and harvest index. This is probably due to a combination of osmotic, ionic and nutrient imbalance effects of salt stress. Specific ionic toxicity was shown to have damaged leaf architecture in most treatments, aggravating as salinity stress increased, consequently resulting in reduced leaf area for photosynthesis. In addition, a lot of photosynthate is diverted towards metabolic processes associated with the plant response and tolerance to salinity stress (Munns and Tester, 2008; Munns and Gilliham, 2015).

Correlation and Factor analysis results showed that the growth and yield components of $P$. vulgaris under synergistic effects of salinity and irrigation regimes were highly salinity-dependent while the water related parameters like transpiration rate, water use efficiency and transpiration use efficiency were strictly dependent on available water for irrigation. This shows that when operating in synergy as occurs often in nature, salinity and water stress could post significant threats to growth and yield of $P$. vulgaris.

\section{Conclusions}

The research gives insights into synergistic effects of salinity and water stress in $P$. vulgaris. Salinity effects on yield, coupled with water stress effects on plant water relations would significantly impede production of this crop in areas where these stressors are prevalent. While some level of yield was realised in all treatments, the significant yield losses of over $400 \%$ in some cases reflect the economic cost of salinity stress. Therefore measures to alleviate soil salinity are necessary for enhanced $P$. vulgaris production in such saline contaminated areas. 


\section{Conflict of interest statement}

Authors declare that they have no conflict of interest.

\section{Acknowledgement}

We thank the Divisional Delegation of Agriculture and Rural Development (MINADER) Meme, for providing premises for the screen house to be constructed. We thank the Kumba District Hospital Laboratory for running chlorophyll analyses. This research was funded with funds from the Research Modernization Allowance of the Ministry of Higher Education, Cameroon, which we hereby acknowledge.

\section{References}

Ashraf, M. A., 2012. Waterlogging stress in plants: A review. Afr. J. Agric. Res., 7(13): 1976-1981.

Azizov, I., Khanisheva, M., Ibrahimova, U., 2013. Effect of salinity on chlorophyll content and activity of photosystems of wheat genotypes. In: Advanced Topics in Science and Technology in China. Springer, pp. 548-551.

Can Chulim, Á., Cruz-Crespo, E., Ortega-Escobar, H.M., Sanchez-Bernal, E.I., Madueno-Molina, A., Bojorquez-Serrano, J.I., Mancilla-Villa, O.R., 2017. Respuesta de Phaseolus vulgaris a la salinidad generada por $\mathrm{NaCl}, \mathrm{Na}_{2} \mathrm{SO}_{4}$ y $\mathrm{NaHCO}_{3}$. Rev. Mex. Cien. Agríc., 8(6): 1287-1300.

Egbe, E. A., Yong, F. E., Ayamoh, E. E., 2014. Evaluation of seedlings of three woody species under four soil moisture capacities. Brit. J. Appl. Sci. Technol., 4(24): 3455-3472.

Elzenga, J. T. M., Van Veen, H., 2010. Waterlogging and plant nutrient uptake. In: Waterlogging Signalling and Tolerance in Plants. Springer-Verlag Berlin Heidelberg, pp. 23-35.

Erhenhi, A., 2020. Effects of drought and flooding on beans (Phaseolus vulgaris L.) and groundnut (Arachis hypogaea L.): a comparison. Bangl. J. Scient. Ind. Res., 55(3): 189-196.

Farooq, M., Wahid, A., Kobayashi N., Fujita, D., Basra, S.M.A., 2009. Plant drought stress: Effects, mechanisms and management. In: Sustainable Agriculture. Springer Netherlands, pp. 153-188.

Gupta, B., Huang, B., 2014. Mechanism of salinity tolerance in plants: Physiological, biochemical, and molecular characterization. Int. J. Genomics, 2014: $1-18$.

Irfan, M., Hayat, S., Hayat, Q., Afroz, S., Ahmad, H.
2010. Physiological and biochemical changes in plants under waterlogging. Protoplasma, 241(1): 3-17.

Kabir, H., Golder, J. 2017. Rainfall variability and its impact on crop agriculture in southwest region of Bangladesh. J. Climatol. Weather Forecast., 5(1): $1-20$.

Majeed, A., Siyyar, S., 2020. Salinity stress management in field crops: An overview of the agronomic approaches. In: Hasanuzzaman, M. (Ed.) Plant Ecophysiology and Adaptation under Climate Change: Mechanisms and Perspectives II. Singapore: Springer Singapore, pp. 1-16.

Munns, R., Gilliham, M., 2015. Salinity tolerance of crops - what is the cost? New Phytol., 208(3): 668673.

Munns, R., Tester, M., 2008. Mechanisms of salinity tolerance. Annu. Rev. Plant Biol., 59: 651-681.

Muthayya, S., Rah, J.H., Sugimoto, J.D., Roos, F.F., Kraema, K., Black, R.E., 2013. The global hidden hunger indices and maps: An advocacy tool for action. PLoS One, 8(6): e67860.

Nadeem, M., Li, J., Yahya, M., Wang, M., Ali, A., Cheng, A., Wang, X., Ma, C., 2019. Grain legumes and fear of salt stress: Focus on mechanisms and management strategies. Int. J. Mol. Sci., 20(4): 127.

Ntukamazina, N., Onwonga, R.N., Somer, R., Mukankusi, C.M., Mburu, J., Rubyogo, J.C., 2017. Effect of excessive and minimal soil moisture stress on agronomic performance of bush and climbing bean (Phaseolus vulgaris L.). Cogent Food Agric., 3(1): 1373414.

Pandey, S. K., Singh, H. 2011. A simple, cost-effective method for leaf area estimation. J. Bot., 2011: 1-6.

Ren, B., Zhang, J., Dong, S, Liu, P., Zhao, B., 2016. Effects of waterlogging on leaf mesophyll cell ultrastructure and photosynthetic characteristics of summer maize. PLoS One, 11(9): 1-22.

Sadeghipour, O., Aghaei, P., 2012. Response of common bean (Phaseolus vulgaris L.) to exogenous application of salicylic acid (SA) under water stress conditions. Adv. Environ. Biol., 6(3): 1160-1168.

Schwinning, S., Starr, B.I., Ehleringer, J. R., 2005. Summer and winter drought in a cold desert ecosystem (Colorado Plateau) Part I: Effects on soil water and plant water uptake. J. Arid Environ., 60(4): 547-566.

Shrivastava, P., Kumar, R., 2015. Soil salinity: A serious environmental issue and plant growth promoting bacteria as one of the tools for its 
alleviation. Saudi J. Biol. Sci., 22: 123-131.

Tabot, P. T., Adams, J. B., 2012. Morphological and physiological responses of Triglochin buchenaui Köcke, Mering \& Kadereit to various combinations of water and salinity: Implications for resilience to climate change. Wetlands Ecol. Manage., 20: 373388.

Taïbi, K., Taïbi, F., Anderrahim, L.A., Ennajah, A., Belkhodja, M., Mulet, J. M., 2016. Effect of salt stress on growth, chlorophyll content, lipid peroxidation and antioxidant defence systems in Phaseolus vulgaris L. South Afr. J. Bot., 105: 306312.

Takahashi, F., Furomori, T., Urano, K., YamaguchiShinozaki, K., Shinozaki, K., 2020. Drought stress responses and resistance in plants: From cellular responses to long-distance intercellular communication. Front. Plant Sci., 11: 1-14.

Tian, L., Bi, W., Liu, X., Sun, L., Li, J., 2019. Effects of waterlogging stress on the physiological response and grain-filling characteristics of spring maize (Zea mays L.) under field conditions. Acta Physiol. Plant., 41(5): 1-14.

Volkov, V., Beilby, M. J., 2017. Editorial: Salinity tolerance in plants: Mechanisms and regulation of Ion transport. Front. Plant Sci., 8, pp. 1-4.

Wang, X., Deng, Z., Zhang, W., Meng, Z., Chang, X., Lu, M. 2017. Effect of waterlogging duration at different growth stages on the growth, yield and quality of cotton. PLoS One, 12(1): e0169029.

\section{How to cite this article:}

Tabot, P. T., Mfombep, M. P., Abeche, A. J., Kedju, N. C., Nyama, B.C., 2021. Ecophysiological responses of Phaseolus vulgaris L. to salinity and irrigation regimes in screen house. Int. J. Curr. Res. Biosci. Plant Biol., 8(2): 11-22. doi: https://doi.org/10.20546/ijcrbp.2021.802.002 